\title{
Mud Crab (Scylla serrata) Culture: Understanding the Technology in a Silvofisheries Perspective
}

\author{
Mirera H. O. David \\ Kenya Marine and Fisheries Research Institute (KMFRI), P.O. Box 81651, Mombasa
}

Keywords: Mud crab, Pens, Cages, Bamboo, Fito, Cost-Return, Conservation

\begin{abstract}
A study was conducted in Mtwapa creek on the north coast Kenya, during 20052007 to evaluate the viability of pens and drive-in cages for mud crab (S. serrata) culture as a mangrove management strategy and alternative source of income for local communities. Other objectives were to assess the effectiveness of drive-in cage construction materials (fito and bamboo) in improving mud crab culture and influences return on investment. The applicability of morphomentric equations in estimating growth was also tested. Four replicate pens $(6 \mathrm{~m} \times 2$ m) were stocked with $2 \mathrm{crabs} / \mathrm{m}^{2}$ while individual drive-in cages $(30 \mathrm{~cm} \times 30 \mathrm{~cm} \times 30 \mathrm{~cm}$ ) were joined to form ten in one group ( 1 replicate) and a total of four replicates used. Uniform feeding was applied for all crabs in pens and drive-in cages using a mixture of fish offal and gastropod meat once a day at $10 \%$ body weight. Specific growth rate and survival of mud crabs were evaluated together with the cost of investment for the three months culture period. Drive-in cages recorded a significantly better survival and growth rate $(53.2 \pm 12.78 \% ; 1.25 \pm 0.42 \mathrm{~g} /$ day $)$ compared to pens $(31.25 \pm 2.95 \% ; 0.68 \pm 0.24 \mathrm{~g} /$ day $) \mathrm{p}<0.05$ while no significant difference was observed between drive-in cages made of different materials (fito and bamboo). A link between growth rate and size of crab was observed, where growth rate decreased with increasing weight. Moulting associated factors contributed highly (45\%) to the total mud crab mortality recorded ( $<<0.05)$; mortality also had a strong positive relationship with moulting $\left(R^{2}=0.79, p>0.05\right)$. Strong relationships existed in morphomentric equations between carapace length and weight $\left(\mathrm{W}=0.0006 \mathrm{~L}^{2.9941} ; \mathrm{R}^{2}\right.$ $=0.86, \mathrm{p}>0.05)$. The construction costs for pens were three times more than those for a similar number of drive-in cages. Cost-return analysis on a per year basis/50 crabs showed that the use of either bamboo or fito as cage construction material was economically viable with a return on capital investment of $122.3-181.7 \%$. Therefore the integration of mud crab culture in mangrove forest is feasible in Kenya.
\end{abstract}

\section{INTRODUCTION}

The mud crab (Scylla serrata) is the only species of the genus Scylla in the Indian Ocean. It has both ecological and economic importance to the marine environment and to the coastal fishing villages (Keenan et al., 1998). The crabs inhabit mangrove forests and are fished commercially throughout the Indo-Pacific. Mud crabs are sought as quality food for local village consumption and for sale in tourist hotels, where they fetch high prices due to their excellent taste, texture and nutritive value (Cowan, 1984; Trino and Rodriguez, 2002).

The mud crab fishery in the Western Indian Ocean (WIO) region is dependent on artisanal fishermen who use traditional capture methods (hook sticks, pots, traps and seine nets). Mud crab aquaculture in the region is small in comparison to Southeast Asia (Mwaluma, 2002). The demand for mud crabs both from local tourist hotels and, in particular, from the export market is large and is growing rapidly in both Kenya and Tanzania (ASCI- 
VOCA 2005). However, due to the unregulated nature of the fishery, there are indications that some local crab populations have decreased significantly as a result of increased fishing effort over time (Francis \& Bryceson; 2001; Mahika et al. 2005). Mud crab population decline along the Kenyan coast has also been associated with mangrove degradation (Abuodha and Kairo, 2001).

Mangrove forest areas have shown positive correlations with annual fishery catches from adjacent offshore fishing grounds in Philippines (Bagarinao, 1998). Similar results were obtained in Kenya, where high abundance and diversity of juvenile fish were found in forested mangrove areas compared to sandy beach flats (Mirera et al., 2005). Loss of mangroves means loss of fishery, income and livelihood for many coastal inhabitants. Since the mangrove recovery process is slow (Kairo et al., 2001), an alternative source of income for coastal communities supportive of mangrove resource management is vital. Such alternatives can be achieved through small scale mud crab aquaculture in the WIO region. These small scale and low investment grow-out crab farms are located within natural mangrove habitats and designed to produce high yields of crabs while maintaining the integrity of the mangrove ecosystem as nursery and feeding grounds for fish (Trino \& Rodriguez 2002).

Mud crabs are successfully cultured in Southeast Asia using wild seed stock for grow-out, where survival is between $30 \%$ and $85 \%$ based on stocking density and feed under pen $\left(200 \mathrm{~m}^{2}\right)$ culture systems (Trino and Rodriguez, 2002). The survival variations have been associated with the cannibalistic nature of $S$. serrata and change in habitat conditions. This aquaculture industry has expanded very rapidly and produced 85,000 tons of crabs in 2005 at a value of US \$281 millions (FAO, 2007). Similar mud crab aquaculture initiatives in Kenya have been minimal with few trials focusing on pen culture (Mwaluma, 2002).

Initial attempts to culture mud crabs in pens at stocking density of $2 \mathrm{crabs} / \mathrm{m}^{2}$ by Mwaluma (2002) yielded a survival of less than $7 \%$, results, which can be attributed to the cannibalistic nature of the crabs and difficulties in harvesting due to lack of adequate drainage in the pens. In the same study, a higher specific growth rate was recorded for crabs in the size group 80.0 - $99.9 \mathrm{~mm}$ carapace length, compared to those of less than $19.9 \mathrm{~mm}$ carapace length. Attempts to increase the weight of undersized sub-adult mud crabs $(<300 \mathrm{~g})$ in drive-in individual cages for a shorter period $(<$ 1 month) in Tanzania showed a mortality of $10 \%$ per month compared to the wild mortality of $2 \%$ per month (ASCI-VOCA, 2005 and Mahika et al., 2005), making such efforts unsustainable.

Previous mud crab culture studies in Kenya have been undertaken in Mtwapa creek, the site of the current study, which uses modifications of the previous methods (Mwaluma, 2002). This study was undertaken to compare growth and survival of mud crabs in pens and drive-in cages built on top of the mud using 'fito' sticks or bamboo with a cover on top. The study also evaluated the return on investment from drive-in cage culture with different cage construction materials in addition to establishing quick growth monitoring morphomentric equations.

\section{MATERIALS AND METHODS}

The study was carried out at Mtwapa mangrove creek near Kwetu Training Centre $\left(03^{\circ}, 56.896^{\prime}\right.$ $\mathrm{S}$ and $\left.039^{\circ}, 42.746^{\prime} \mathrm{E}\right)$ at about $20 \mathrm{~km}$ north of Mombasa city (Figure 1). The site is an intertidal mangrove area with small natural channels, which tend to make the upper layer of the substrate sandy and the lower section muddy. The channels help to completely grain the area at low tide and provide for rapid influx of ocean water as the tide rises. The site was inundated twice daily at each high tide. The culture area was covered by natural mangrove stands, being dominated by Rhizophora mucronata, Sonneratia alba and Avicennia marina at a ratio of 4: 2: 1 (per meter square) respectively as counted during the experiemntal period. The general tree height in the area was approximated to be between 3 $\mathrm{m}$ and $8 \mathrm{~m}$ and a canopy cover of more than $60 \%$.

All the culture structures were designed following silvofisheries techniques such that the function of mangroves as nursery grounds for commercially exploited finfish and crustaceans were not hampered (Trino and Rodriguez, 2002). Four replicate rectangular pens of size $6 \mathrm{~m} \times 2 \mathrm{~m}$ were enclosed with 'uzio' (sticks tied together to form a mat) as used by local fishermen to trap fish in mangrove channels and other intertidal areas. The 


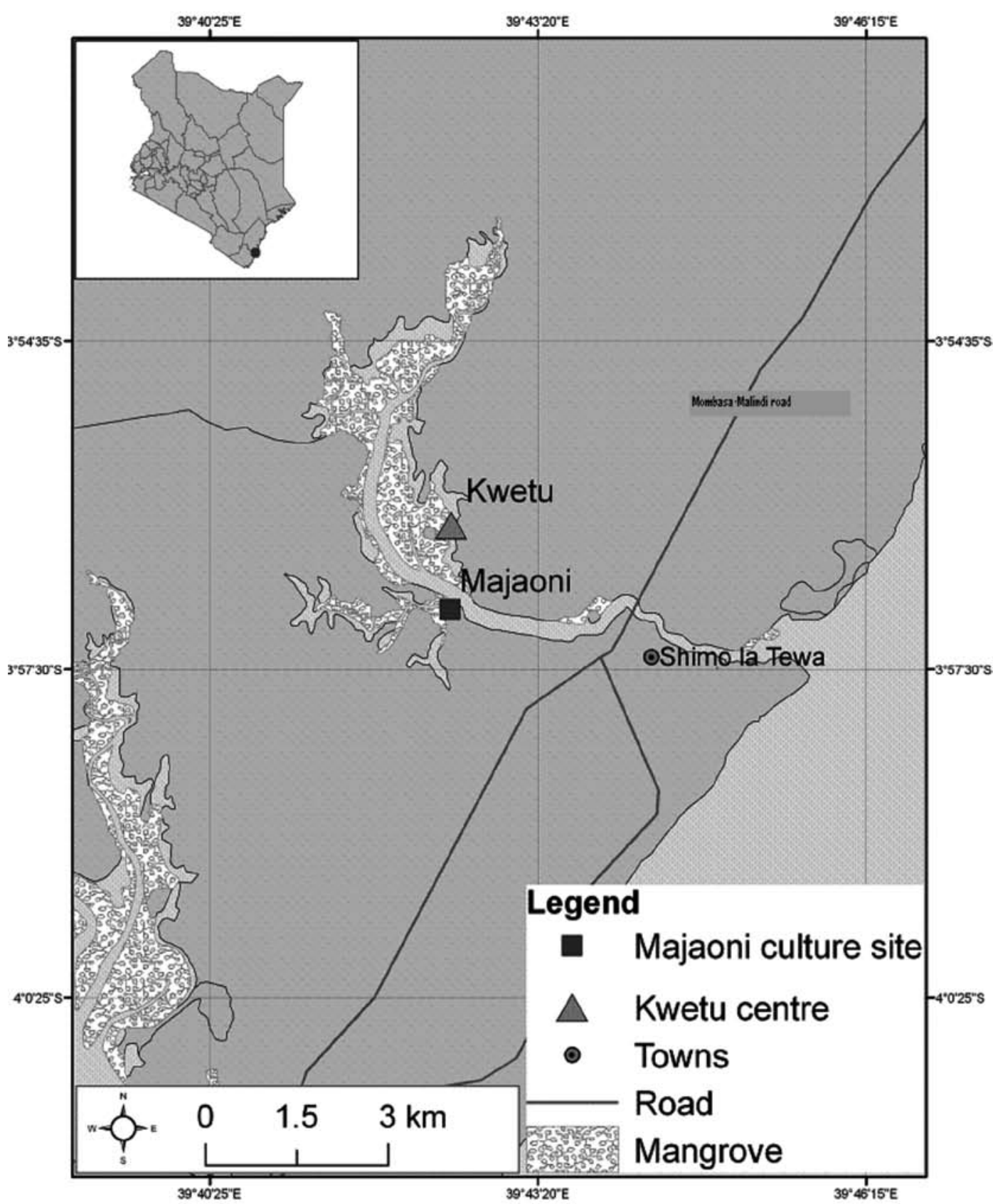

Fig. 1. Map showing Mtwapa creek and the mangrove area near Kwetu Training Centre where the study was carried out

uzio was lined from the inside with 'pokomo' mats and the two tied onto a framework of mangrove poles as support structures at intervals of $2 \mathrm{~m}$ with an effective height of $3 \mathrm{~m}$. The bottom margins of the Uzio and pokomo mat were buried $60 \mathrm{~cm}$ into the mud by digging channels along the pen area and trimming some mangrove roots without mangrove tree felling. Two small canals $(50 \mathrm{~cm} \times 50 \mathrm{~cm} \times 30$ $\mathrm{cm})$ were dug in each pond to maintain water in the pen during the low tides.

In the same mangrove forest site, four replicate drive-in individual mud crab cages each $30 \mathrm{~cm}$ x $30 \mathrm{~cm}$ x $30 \mathrm{~cm}$ were constructed using each construction material (fito and bamboo) (see Figure 
2). The drive-in cage structure was constructed in the open sections with minimal root trimming and taking into consideration the characteristic of $S$. serrata to bury itself into the mud. Lower margins of the drive-in cages were buried about $30 \mathrm{~cm}$ while the above ground margin was also $30 \mathrm{~cm}$ high. Half of the cages were constructed using split bamboos that were $60 \mathrm{~cm}$ in length and the other, fitos (small sticks of the neem tree and other coastal thickets). The bottom sections of the drive-in cages were not covered purposely to allow for the crab to burrow and hide itself in the mud at low tide, while the upper section was covered with a lid made of either bamboo or fito. The cages were sewn together using binding wire or thin manila ropes. Cage covers were permanently attached at one point and the other tied with ropes to allow opening only for monitoring and daily feeding to ensure no crab escape at high tide.

To avoid further degradation of the mangrove benthic biodiversity and roots, a boardwalk about
1 meter above the ground was constructed using boriti (mangrove poles) and timber. This improved accessibility during monitoring and feeding, in addition to reduced mangrove root rot from constant trampling. Also the number of mangrove tree stands in and around the pens and cages was counted, while intactness of the root system was assessed to enable comparison at the end of the experiment. Daily tidal flushing was adequate to prevent deterioration of water in this study (Trino and Rodriguez, 2002) however; incoming tidal water was monitored weekly for temperature, $\mathrm{pH}$, salinity and dissolved oxygen.

Crab fishers were contracted to collect crabs from the creek for stocking in this study. Their main capture methods were hook sticks and seining. The former was used to get them out of their holes in the mangroves at low tide while the later was used to seine them along the shores at both low and high tides. In total 480 crabs were collected and used for the two culture trials that took three

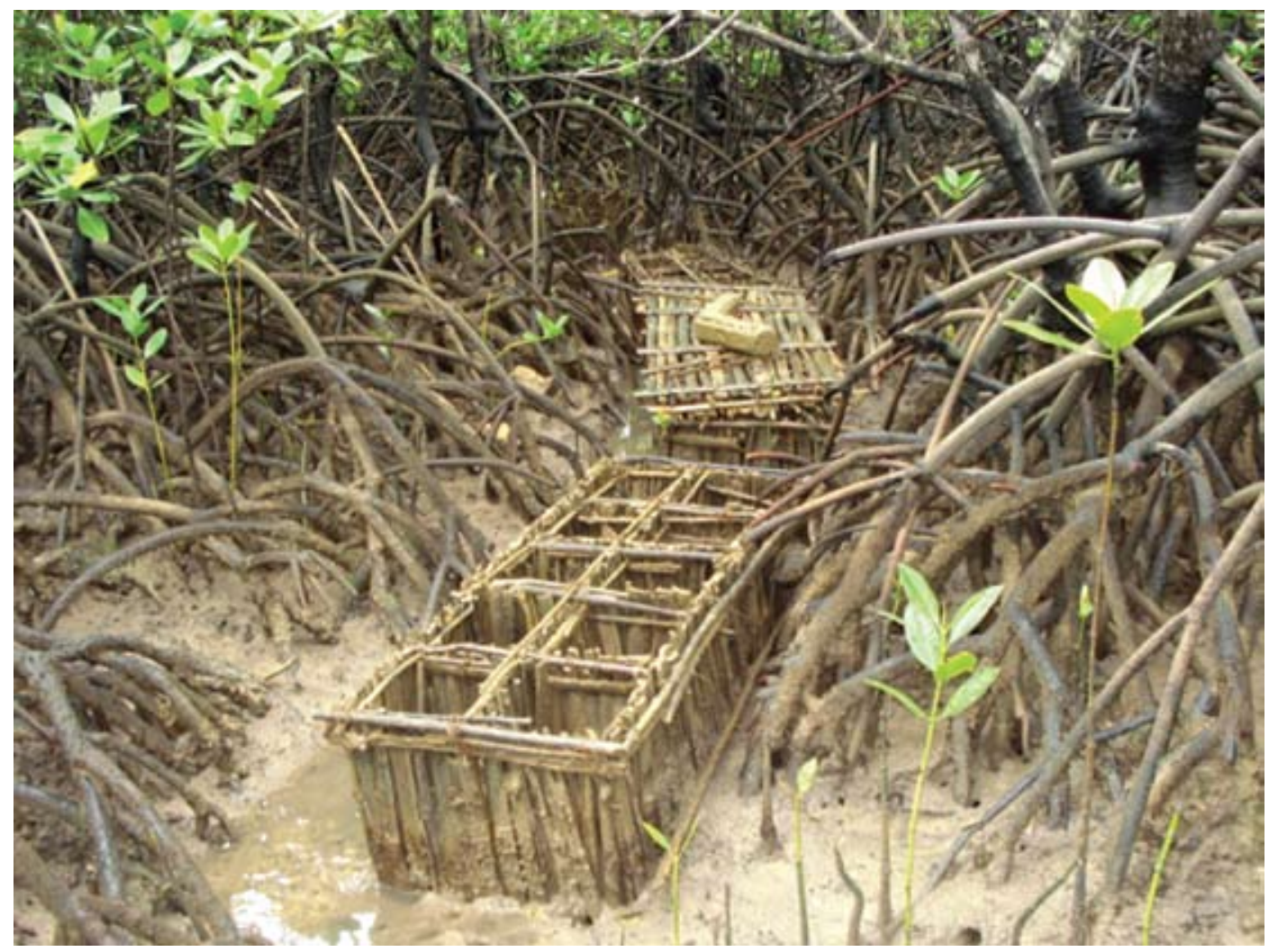

Fig. 2. A drive-in mud crab cage set among mangrove prop roots near Kwetu Training Centre showing the ten individual compartments and cover installation to prevent escape 
months each. Stocking was done for both males and females without regard to sex ratio considerations, while the crab stocking size was less than $350 \mathrm{~g}$ but more than $50 \mathrm{~g}$ total weight. The stocking density in pens was $2 \mathrm{crabs} / \mathrm{m}^{2}$ with mixed sex while cages were stocked with one crab per compartment. At stocking all crabs were examined for morphological condition, total weight in grams was recorded and carapace width and length measured to the nearest millimeter using vernier calipers.

Daily monitoring of cages and pens was undertaken and the numbers of moulted crabs were recorded along with their mortality. Mortality was correlated with stage of moulting, i.e. at the beginning of the process, midway through and after successful moulting as well as predation or cannibalism after a successful moult. Escape by cutting walls or poor covering or poor construction was also noted. Crabs in both treatments were fed with a mixture of fish offal and gastropod meat at $10 \%$ body weight daily at incoming tide. The feed was chopped into small pieces before being weighed and spread in the pens and individual cage compartments. Body weight, carapace width and length of crabs were measured monthly. Sampling was carried out in the early morning at low spring or neap tide and all crabs in the cages were sampled while only $10 \%$ of those in the pens were sampled to reduce stress, due to the tedious capture exercise of getting them from their holes. Harvesting was done at the end of three months when an economic analysis was undertaken.

The mean body weight, growth rate, survival, and cost of production were calculated from the total harvest. Means of these parameters were compared by analysis of variance and Duncan's multiple range tests at $5 \%$ level of significance. Cost benefit analysis for cages was calculated to establish return on investment while morphomentric equations were calculated from all the crab populations involved in the study.

\section{RESULTS}

The range of values for incoming Indian Ocean water quality parameters recorded during the culture experiment were: salinity 25-34 ppt, temperature $28-30^{\circ} \mathrm{C}, \mathrm{pH} 7.5-8.9$ and dissolved oxygen $5.5-12 \mathrm{mg} / \mathrm{l}$ which tended to vary slightly with time of day. No physical effect was observed on the mangrove tree stands at the end of the culture experiment in the pen and cage culture sites apart from the less than 5\% mangrove prop root trimming during construction of the culture facilities.

Table 1 shows the mean weight and carapace length (initial and final), overall growth, growth rate and survival of crabs stocked in drive-in cages and pens. Growth rate and survival of crabs showed no interaction within treatments (cages and pens). Therefore data were pooled for each treatment and tested with ANOVA for between treatment differences. There was a significant difference in growth rate between pens ( $0.7 \mathrm{~g} /$ day) and cages ( 1.3 $\mathrm{g}$ /day) (Table 2). Significant differences were also recorded in survival and final weight attained (Table 1). There were no significant differences $p>0.05$ observed for initial stocking weights, carapace widths and growth.

Growth rate was dependent on crab size. Small crabs had higher growth rates, which

Table 1: Mean \pm stdev pooled initial and final weight, carapace width $(\mathrm{CW})$, growth, specific growth rate (SGR) and survival of mud crabs (Scylla serrata) reared in pens and drive-in cages with their n-values

\begin{tabular}{lllll}
\hline Parameter & \multicolumn{1}{c}{ Cages } & n & Pens & n \\
\hline Initial weight $(\mathrm{g})$ & $258.6 \pm 123.5^{\mathrm{a}}$ & 140 & $122.8 \pm 59.1^{\mathrm{a}}$ & 340 \\
Final weight $(\mathrm{g})$ & $336.5 \pm 106.5^{\mathrm{a}}$ & 75 & $146.1 \pm 73.4^{\mathrm{b}}$ & 106 \\
Growth (g) & $67.9 \pm 16.9^{\mathrm{a}}$ & 140 & $50.6 \pm 14.9^{\mathrm{a}}$ & 340 \\
Initial carapace width (mm) & $106.9 \pm 1.8^{\mathrm{a}}$ & 140 & $85.3 \pm 1.7^{\mathrm{a}}$ & 340 \\
Final carapace width (mm) & $118.6 \pm 1.7^{\mathrm{a}}$ & 75 & $89.2 \pm 1.7^{\mathrm{b}}$ & 106 \\
Specific growth rate (g/day) & $1.3 \pm 0.4^{\mathrm{a}}$ & 140 & $0.7 \pm 0.2^{\mathrm{b}}$ & 340 \\
Survival (\%) & $53.2 \pm 12.8^{\mathrm{a}}$ & 140 & $31.3 \pm 2.9^{\mathrm{b}}$ & 340 \\
\hline
\end{tabular}

* Data were pooled for each culture treatment since there were no interactions within the culture systems (pens and drive-in cages). Values with similar superscripts for the same parameters in the treatments are not significantly different $(\mathrm{p}>0.05)$. $\mathrm{n}$ : represents the number of crabs involved when making the calculations for both cages and pens 
Table 2: Analysis of variance and Duncan multiple range test results comparing mud crab growth rate in pens and drive-in cages

\begin{tabular}{lcccc}
\hline $\begin{array}{l}\text { Source of } \\
\text { variation }\end{array}$ & SS & $\begin{array}{c}\text { Degr. of } \\
\text { Freedom }\end{array}$ & F & P \\
\hline Intercept & 6.77 & 1 & 34.89 & 0.000 \\
Cage* pen & 0.60 & 1 & 3.11 & 0.047 \\
Error & 3.10 & 82 & & \\
\hline
\end{tabular}

decreased with increase in size (Figure 3). Moulting associated factors were found to contribute to $45 \%$ of mortalities in both cages and pens (Figure 4), while cannibalism contributed $10 \%$ and escape $20 \%$. There was a strong positive relationship $\left(\mathrm{R}^{2}\right.$ $=78.6 \%$ ) between mortality and moulting (Figure 5 ) indicating that if moulting associated mortalities were controlled, mud crab survival could be more than $70 \%$ and therefore more profitable.

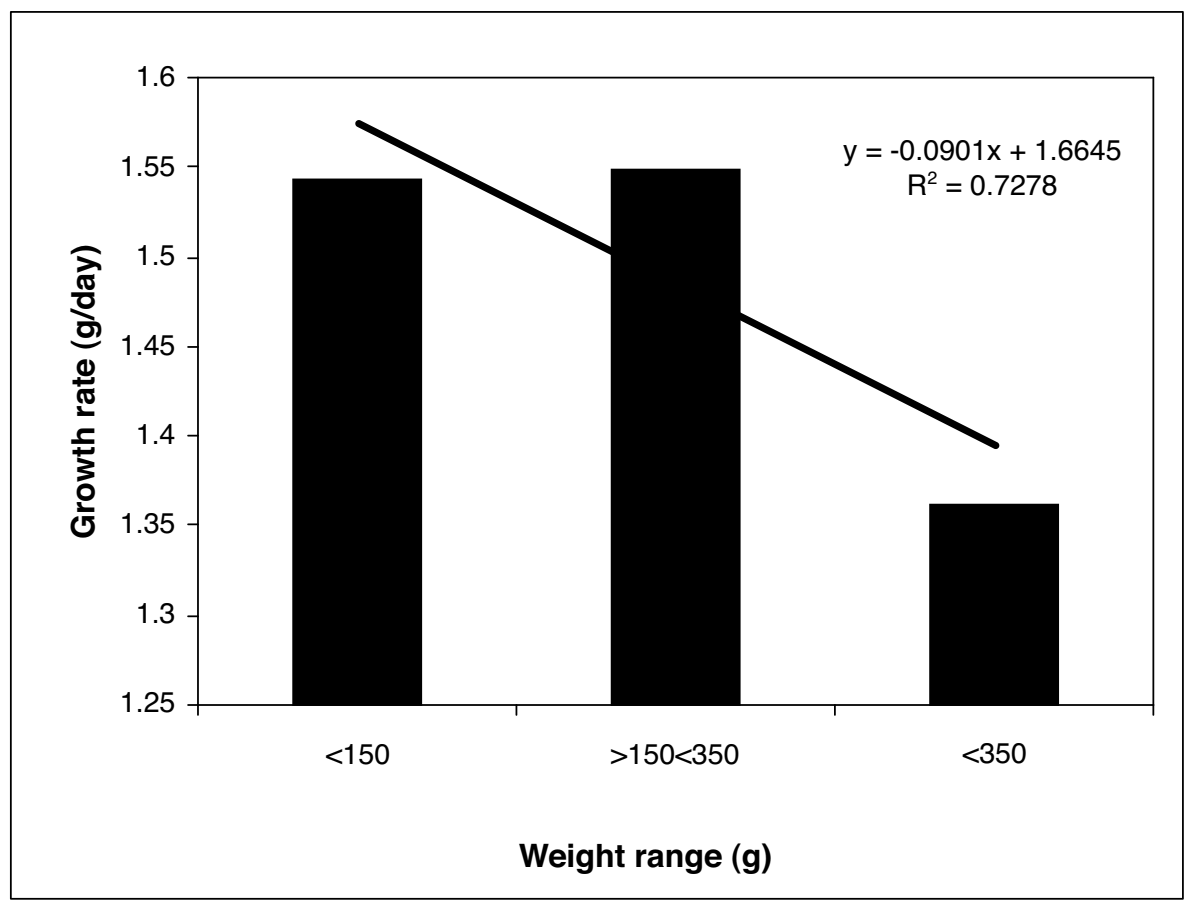

Fig. 3. Influence of weight on growth rate in mud crabs (Scylla serrata) stocked in drive-in cages over a three months culture experiment

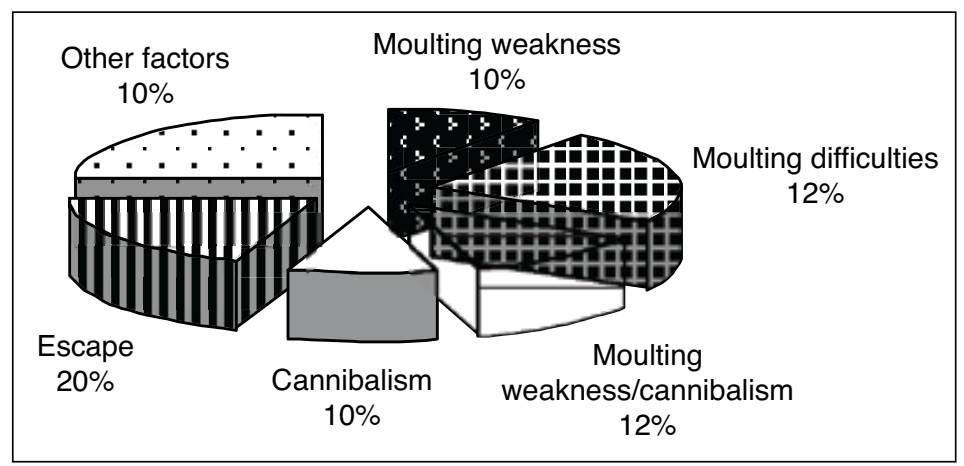

Fig. 4. Contribution of factors towards survival of mud crabs as observed during the three months study for the two culture systems. (All mortalities that occurred on successfully moulted crabs within $\mathbf{4 8}$ hours without having any physical injuries were classified as "moulting weakness"; mortalities that occurred before a crab could successful moult, were considered to have "moulting difficulties" while those that moulted successfully and then cannibalized or predated on within 48 hours were classified as "moulting weakness/cannibalism") 


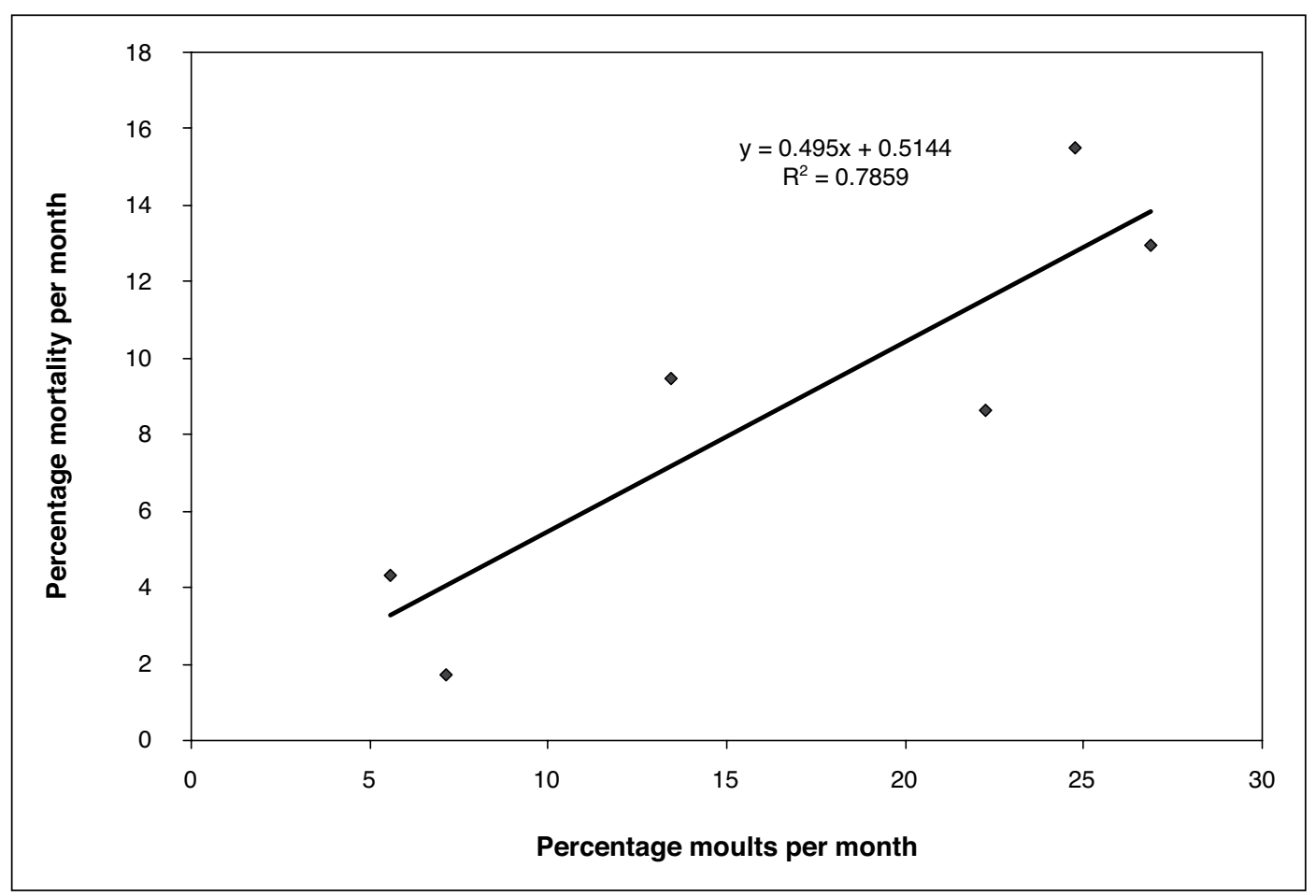

Fig. 5. Relationship between mortality and moulting of mangrove mud crab in pens and cages during the three months culture period

In comparison of drive-in cage culture structures made of bamboo and fito, there was no significant difference in growth rate (bamboo- $1.29 \mathrm{~g} / \mathrm{day}$, fito$1.24 \mathrm{~g} /$ day; $\mathrm{P}>0.05$ ); survival (bamboo- $48.9 \%$, fito-57.7\%; $\mathrm{P}>0.05$ ); or moulting frequency (bamboo- $38.1 \%$, fito- $47.6 \%$; $\mathrm{P}>0.05$ ). However, construction cost for one pen holding 24 crabs at rate of $2 \mathrm{crabs} / \mathrm{m}^{2}$ was $100 \mathrm{USD}$, which was effective only for two culture periods of 3 months while drive-in cages with similar culture capacity was 30 USD with an efficiency of more than 4 culture periods (1 year), based on the long term culture observations after the three month experiments. Other advantages of a drive-in cage culture over pen culture systems included easy individual crab management and monitoring, assured feed allotment for individual crabs, feeding adjustment, cleaning and repair of the culture set up and higher culture capacity within a small space.

Morphomentric analysis indicated a strong relationship between biomass and carapace length $\left(\mathrm{R}^{2}=0.86, \mathrm{p}>0.05\right)$ for combined males and females (Figure 6). There was a similarity between the relationships obtained for individual sexes (females-W $=0.002 \mathrm{~L}^{2.6889} ; \mathrm{R}^{2}=0.89, \mathrm{p}>$ 0.05: males-W $\left.=0.0002 \mathrm{~L}^{3.2053} ; \mathrm{R}^{2}=0.89, \mathrm{p}>0.05\right)$ and that of combined sexes (male and female) suggesting dual applicability. The results suggest that the combined equation can be used to calculate mud crab biomass or carapace length given either of the parameters that could help to reduce sampling related stresses.

Analysis of drive-in cage building materials (fito and bamboo), was found to be effective on the short term using bamboos by reducing the rate of crab escape while continued culture experiments using the same structures over one year, bamboos tend to rot faster than fito. The total investment (Table 3) comprised capital investment cost and operating costs (variable and fixed costs). Labour and feeds contributed the highest percentage to costs for both fito cages (70.2\%) and bamboo cages $(65.2 \%)$. The annual net profit for fito drive-in cages was more (129. 38 USD) than for bamboo (93.76 USD) which provided a higher return on investment in the former. 


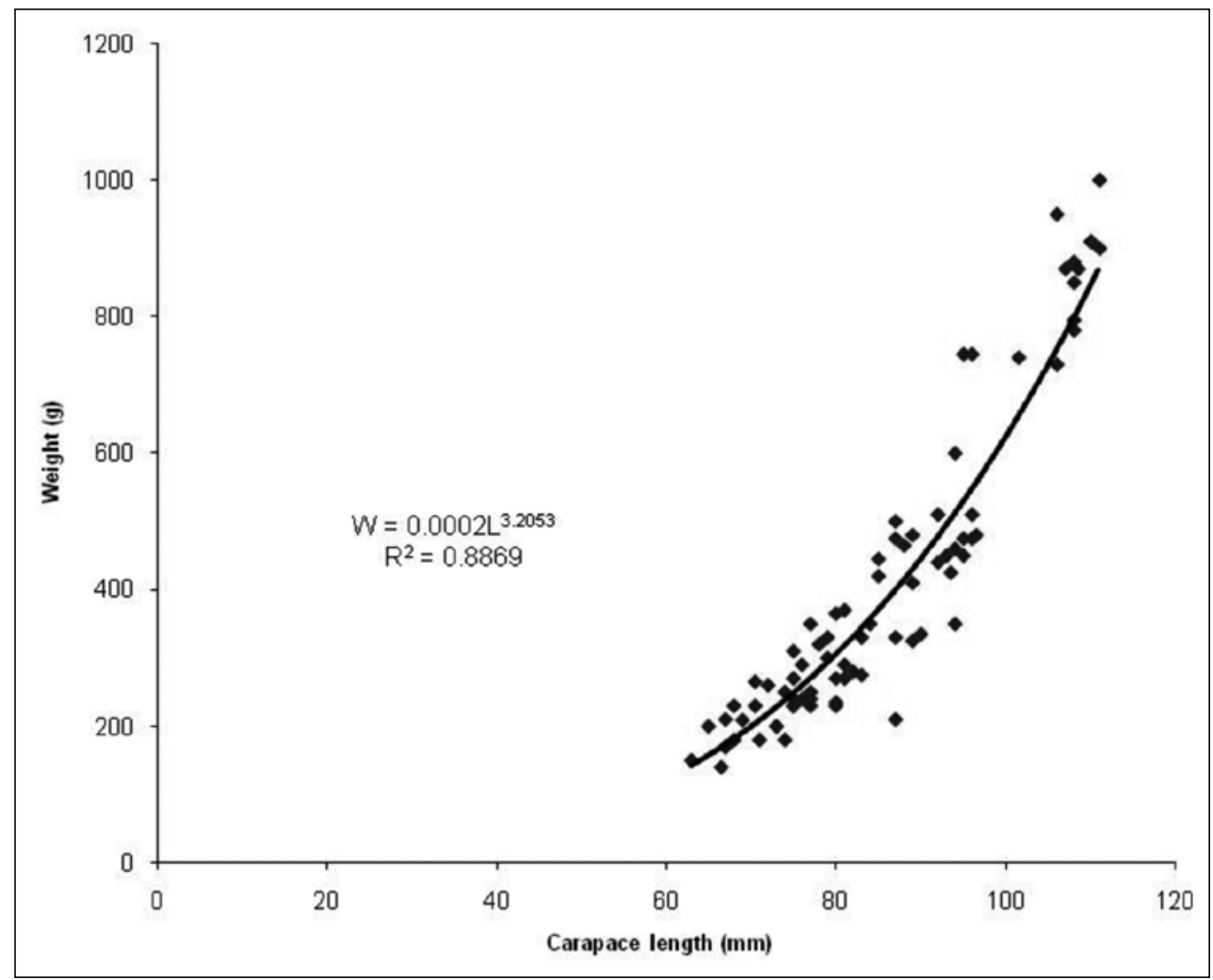

Fig. 6. Morphometric relationships (weight / carapace length) in mud crabs for combined sexes

Table 3: Cost-return analysis of mud crab culture using drive-in cages in a mangrove forest comparing fito sticks and bamboo as cage construction materials

\begin{tabular}{|c|c|c|c|c|}
\hline 1. Technical basis & Details & Fito & & Bamboo \\
\hline Stocking rate/run & & $50 \mathrm{pcs}$ & & $50 \mathrm{pcs}$ \\
\hline Average weight at stocking & & $300 \mathrm{~g}$ & & $300 \mathrm{~g}$ \\
\hline Survival at harvest & & $57.74 \%$ & & $48.96 \%$ \\
\hline Average daily growth & & $1.24 \mathrm{~g}$ & & $1.29 \mathrm{~g}$ \\
\hline Culture period & & 3 months & & 3 months \\
\hline Number of cropping/year & & 4 & & 4 \\
\hline Average wgt at harvest & & $411.6 \mathrm{~g}$ & & $416.1 \mathrm{~g}$ \\
\hline Total yield per run & & $10.03 \mathrm{~kg}$ & & $8.52 \mathrm{~kg}$ \\
\hline \multirow[t]{2}{*}{ 2. cost of production/yr (USD) } & Fito & & Bamboo & \\
\hline & Quantity & Cost USD & Quantity & Cost USD \\
\hline Bamboo (pc) & & & 3 & 6.08 \\
\hline Fito(roll) & 5 & 2.02 & & \\
\hline Binding wire(roll) & 2 & 2.43 & 2 & 2.43 \\
\hline Labour & 1.5 & 4.05 & 2 & 5.41 \\
\hline Crab seed stock & 50 & 10 & 50 & 10 \\
\hline Repair and maintenance & $0.68 /$ run & 2.72 & $0.68 /$ run & 2.72 \\
\hline Feeds and labor & 12.5USD/run & 50 & $12.5 \mathrm{USD} / \mathrm{run}$ & 50 \\
\hline Total costs & & 71.22 & & 76.64 \\
\hline 3. Cost and return (USD) & & Fito & & Bamboo \\
\hline sales of production/run (5USD/kg) & & 50.15 & & 42.6 \\
\hline sales of production per year & & 200.6 & & 170.4 \\
\hline Net profit (USD) & & 129.38 & & 93.76 \\
\hline Return of investment & & $181.7 \%$ & & $122.3 \%$ \\
\hline
\end{tabular}




\section{DISCUSSION}

Mud crabs in pens do not damage enclosed mature trees suggesting that pens may be set up in sites with fully grown trees, but not in mangrove seedling areas, where they may cause damage (Dahdouh Guebas et al., 1998). The observation was quite different in cages, where in the first week crabs aggressively cut both the fito and bamboo in order to escape. Daily monitoring of cultures will also likely result in a reduction of illegal mangrove cutting, and thus helps sustain mangrove forest management. The boardwalk helped to reduce disturbance and deterioration of benthos.

The culture area was flooded daily by tidal ocean water that reduced local effect on water quality. Water quality values recorded in this study were within the optimal ranges for mud crabs as recorded by previous studies in the area (Mwaluma, 2002) and elsewhere (Baliao et al., 1999; Chang, 1997; Trino et al., 1999a,b and Hill, 1980). Daily tidal flushing in the culture area was seen to be adequate in preventing deterioration of environmental quality variables.

Mud crabs grew in drive-in cages (individual cages) faster than in pens at a stocking density of $2 \mathrm{crabs} / \mathrm{m}^{2}$ as indicated by the specific growth rates and final weight and carapace width attained. Specific growth rates were higher than those observed by Trino and Rodriguez (2002) though their culture period was 160 days compared to the present study of 90 days. The current growth rates were also higher than those recorded by Mwaluma (2002), whose lower growth rates could be associated with the lack of a daily flooding tide leading to high water temperatures in the pens. Significant growth in drive-in cages compared to pens could be associated with the reduced energy loss from movement in the 'zero grazing' cage-unit and its subsequent conversion to growth compared to animals kept in pens where movement is not so restricted. The study observed a decrease in mud crab growth rate as biomass increased, a feature which has been documented by other workers (Mwaluma, 2002; Bensam, 1986). Bensam (1986) found an increase in weight ranging from 2.3 times in crabs in the weight range $51-60 \mathrm{~g}$, to 3.5 times in the weight range from 1-10 $\mathrm{g}$ during a period of
3 months. Such a trend is most likely linked to the sexual maturation occurring when the carapace width is about $75.0 \mathrm{~mm}$. From this stage onwards much of the food intake goes to reproduction (Tongdee, 2001) at the expense of growth.

An investigation of the effect of culture facilities on survival indicated lower values for pens compared to cages. Survival in pens was $31.3 \%$, being higher than those reported by Mwaluma (2002), but similar to those by Trino and Rodriguez (2002) at a stocking density of $1.5 \mathrm{crabs} / \mathrm{m}^{2}$, though the survival was significantly lower than that recorded by Trino et al., (1999a) at a stocking density of $0.5 \mathrm{crabs} / \mathrm{m}^{2}$. Lower survival in the current study may be related to the larger size of crabs stocked, or higher density, which may have resulted in increased cannibalism. Drive-in cage culture significantly increased survival as observed in other studies using pen culture (Chang and Ikhwanuddin, 1999). Continued use of the drive-in cage culture facilities over one year, revealed that bamboo or fito did not significantly affect growth or survival. Therefore both materials can be used interchangeably depending on availability as a strong point for mangrove conservation.

Despite the many factors causing mortality in cultured mud crabs, the highest percentage was attributed to moulting associated factors (45\%); inability to successfully moult, mortality immediately after moult and injury on soft moulted bodies. Studies in Indonesia by Cholik and Hunafi (1992) pinpointed the main cause of mortality as moulting, while Fielder et al. (1988) observed that moulting and post moult soft crabs are easily cannibalized and predated upon as observed in this study. This could be the reason for higher survival in the individual drive-in cage compartments observed in this study where the chance of cannibalism and predation were limited compared to culture in pens. Moulting stress may be another cause of associated mortalities. Application of the morphomentric equations developed in this study, which are similar to those of Khan and Alam (1991), might be used in the reduction of such mortalities.

Due to higher construction cost for pens, no profit could be realized from the system. They were therefore eliminated from the cost-benefit analysis in community mud crab culture. Production, net profit and return on investment were higher in mud 
crab cages made of fito compared to those made of bamboos. Culture of more than 50 mud crabs at a time in drive-in cages yields more than $120 \%$ return on investment in one year similar to what has been established in Philippines using pens due to the cheap cost of construction materials (Agbayani, 2001; Trino and Rodriguez, 2002). Net profit and return on investment increases with number of mud crabs cultured after the minimum of fifty. There are also chances for further improvement in profitability through reduction in moulting-related mortalities, escape and better harvesting of crabs as they attain marketable size.

\section{CONCLUSION}

It is evident that mud crab culture in drive-in cages improves both growth and survival, and is low cost and profitable in the long run compared to pen culture. The use of either pen or drive-in cage culture in mangroves is both economically and ecologically viable since there is no need to remove mangroves or build aquaculture ponds. In addition, the use of fito sticks or bamboo in construction of mud crab cages has no significant effect on profitability in the long run; however, bamboo planting is encouraged for its multipurpose use to ease pressure on mangrove forests.

For effective mud crab aquaculture in East Africa, there is a need to address the issue of seed supply, which calls for further studies on the recruitment and juvenile settlement of $S$. serrata. More research is needed to understand mud crab biology particularly moulting and its impact on survival as a key factor in successful mud crab aquaculture.

Acknowledgement-This study was part of the project on coastal livelihood in Kenya funded by SIDA/SAREC through CORDIO East Africa. I acknowledge the field support of the mariculture assistants; Renson Washe and Abdhallah Mtile. My appreciation also goes to Kwetu Training Centre for office space and being the custodians together with the Kenya Forest Service for the mangrove forest area used in this study.

\section{REFERENCES}

Abuodha, P; and Kairo, J. G. (2001). Human induced stresses on mangrove swamps a long the Kenyan coast. Hydrobiologia. 458.

ACDI/VOCA (2005). Sub sector and value chain analysis for mud crabs for Tanga coastal belt. ACDI/VOCA SEEGAAD, Final project report Match Maker Associates LTD. 50pp

Agbayani, R. F. (2001). Production economics and marketing of mud crabs in the Philippines. Asian Fish. Sci. 14: 201-210.

Baliao, D. D., De Los Santos, M. A. and Franco, N. M. (1999). Pen culture of mud crab in mangroves. SEAFDEC Aquaculture extension manual, No. 29, March 1999. 10pp.

Bensam, P. (1986). Culture experiment on the crab Scylla serrata (Forskal) at Turiconin during 1975 - 1977 to assess growth and reproduction. Proc. Symp. Coast. Aqua. 4: 1183-1189.

Chang, W. W. (1997). Pen culture of mud crabs in the mangrove ecosystems in Sarawak (East Malaysia). Aqua. Asia II no. 4 Oct - Dec. pp. 3-5.

Chang, W. W. S. and Ikhwanuddin, A. M. (1999). Pen culture of mud crabs, genus Scylla, in the mangrove ecosystems of East Sarawak, Malaysia, pp. 83-88. In: Keenan, C. P. and A. Blackshaw (eds) Mud crab Aquaculture biology. Proceedings of an international scientific forum held in Darwin, Australia, 21-24 April 1997, ACIAR Proceedings No. 78, 216 p.

Cholik, F.and Hanafi,A., (1992). A review of the status of the mud crab (Scylla spp.) fishery and culture in Indonesia. In: Angel, C. A. (Ed.), The Mud Crab. Report of the Seminar on Mud Crab Culture and Trade. Bay of Bengal Programme, Madras, India, pp. 13-17.

Cowan, L. (1984). Crab Farming in Japan, Taiwan and the Philippines. Queensland Department of Primary Industries, Brisbane, Qld. Australia. Information series Q184009, pp. 43-61.

Dahdouh-Guebas, Verneirt, F. M., Tack, J. H., Van Spreyboeck, D. and Koedam, N. (1998). Propagule predators in Kenyan mangroves and their possible effect on regeneration. Mar. Freshwat. Res. 49: 345-350.

FAO (2007). Food and agricultural organization of the United Nations (FAO) Fishery Department. Global Aquaculture Production 1950-2005.

Fielder, D. S., Mann, D. L. and Heasman, M. P. (1988). Development of intensive pond farming techniques for the mud crab, Scylla serrata (Forskal) in Northen Australia. FIRTA Project Report 86/9, 37p. 
Francis J, and Bryceson I. (2001). Tanzanian coastal and marine resources: some examples illustrating questions of sustainable use. Chapter 4 in Ahmed, J. et al. "Lessons learned - Case Studies in Sustainable Use" IUCN, Gland, Switzerland. pp. 76-102.

Hill, B. J. (1980). Effects of temperature and feeding activity in the mud crab Scylla Serrata. Mar. Biol. 59, 189-192.

Kairo, J. G; Dahdouh-Guebas, F; Bosire, J; and Koedam, N (2001). Restoration and management of mangrove systems - a lesson for and from the East African region. S. Afri. J. of Botany: 67: 383-389.

Keenan, C. P., Davie, P. J. F. and Mann, D. L. (1998). A revision of the genus Scylla De Haan, 1833 (Crustacea: Decapoda: Brachyura: Portunidae). Raffles Bull. Zool. 46, 217-245.

Khan, G. Md. and Alam, F. Md. (1991). The mud crab fishery and its bio-economics in Bangladesh. Proceedings of the South East Asian Workshop on Scylla serrata. 1991.

Mahika C, Mhitu H. and Kuboja B. (2005). Rapid assessment of abundance and biomass of the mangrove crab (Scylla serrata.) and its mariculture development on the Tanga coast. Report prepared for ACDI/VOCA Tanzania's
Smallholder Empowerment \& Economic Growth through Agribusiness \& Association Development (SEEGAAD) Project, Tanga, Tanzania.

Mwaluma J. (2002). Pen culture of the mud crab Scylla serrata in Mtwapa mangrove system, Kenya. Western Indian Ocean J. Mar. Sci. Vol. 1, No. 2, pp. 127-133.

Mirera H. O. D., Kairo, J. G., Waweru, F. K. and Kimani, E. N. (2005). Assessment of mangrove fisheries in relation to mangrove forest stand and substratum type. 4th WIOMSA Scientific Symposium (Abstract) Pp 78.

Tongdee, N. (2001). Size distribution, sex ratio and size at maturity of mud crabs (Scylla spp.) in Ranong Province, Thailand. Asian Fish. Sci. 14: 113-120.

Trino, A. T., Millamena, O. M. and Keenan, C., (1999a). Commercial evaluation of monosex pond culture of the mud crab Scylla species in the Philippines at three stocking densities. Aquaculture 174, 109-118.

Trino, A. T., Rodriguez, E. M., Coniza, E. B. and Juanga, B. P. (1999b). Mud crab. Aquaculture extension manual No. 27. SEAFDEC Aqauculture Department, Iloilo, Philippines, 32 pp.

Trino A.T, Rodriguez E. M. (2002). Pen culture of mud crab Scylla serrata in tidal flats reforested with mangrove trees. Aquaculture. 211:125-134. 
